\title{
Effectiveness and Challenges in Evangelization in the Small Christian Communities in the Catholic Church in Vihiga County, Kenya
}

\author{
Dr. Rose Njoroge* \\ Department Of Religion, Theology and Philosophy, Maseno University, P.O Box 333-40105, Maseno, Kenya \\ *Corresponding Author \\ Dr. Rose Njoroge
}

\section{Article History}

Received: 20.07.2019

Accepted: 06.08.2019

Published: 30.09 .2019

\begin{abstract}
This paper investigated effectiveness and challenges in evangelization in the Small Christian Communities in the Catholic Church. Specifically, the study set to analyse the effectiveness of Small Christian Communities (SCCs) in evangelization and explore the challenges encountered in evangelization in these SCCs. The study was based on both primary and secondary data. The study was conducted in 274 SCCs in the five parishes in the Catholic Church in Vihiga County. The key mission of the church is to evangelize to all. The Catholic Church used SCCs as agents of evangelization, therefore prompted and a need for analysis of how effective they have been and if they are challenges encountered in fulfilling the mission.
\end{abstract}

Keywords: Evangelization, Effectiveness, Challenges, Small Christian Communities, Catholic Church.

\section{INTRODUCTION}

\section{BACKGROUND}

The Catholic Church ,like any society is made up of various ecclesial groups such as lay organizations like Legion of Mary, Sacred Heart of Jesus, Divine Mercy Catholic Men Association, Catholic Women Association, Youth groups and SCC among others as pointed out in Gaudium et Spes in Flannery [1]. A renewed expression of SCCs follows the injunction of Vatican II which views the Church as the "People of God." Lumen Gentium in Flannery [1] maintains that "Jesus Christ, the mediator between God and human, established and ever sustains here on earth his holy Church, the community of faith ... through which he communicates truth and grace to all human beings". The mission of the SCCs is to bring the Church closer to the faithful in small groups as members find a connecting cord between their faith and daily life situations. Thus, the communities are identified through the celebration of the liturgy as a small group; an attempt to be sensitive to life events and to celebrate them in a prayerful way and involvement in and service to society.

For effective pastoral work, the Catholic Church introduced a system of Jumuiya Ndogo Ndogo za Kikristo- Small Christian Communities (SCCs) - and the involvement of lay people in Church activities became significant. The movement to form SCCs or basic ecclesial communities is a worldwide phenomenon among the Catholic faithful. The SCCs have been formed in various places for many reasons including: a shortage of priests, a desire for communal liturgy, a desire for cooperation and fellowship, a desire for re-interpretation of the gospel in an existing situation, a desire to come together around a common issue, among many other reasons $[2,3]$. Today Catholics are being divided into SCCs made up of small units or families that live within certain neighbourhoods. From these SCCs, leaders are selected to represent the faithful in sub-parishes, parishes, the diocese, and in the National Lay Council (NLC), Kamwendo [4].

Kurgat [5] asserted that the building of SCCs was adopted as a pastoral priority by the bishops of Eastern Africa in 1973.This was justified by the fact that while the Church of Christ is universal, it is a communion of SCCs of Christians rooted in their own society. Church life must be based on the communities in which everyday life and work takes place. These basic Christian communities are manageable social groupings whose members can experience real interpersonal relationships and feel a sense of communal belonging both in living and working. The Catholic bishops felt that building SCCs was the best way of safeguarding human values and of rooting the Church in the life and culture of the people. In this regard, it was agreed upon that creative pastoral approaches are needed today to adequately respond to the life situations of our people and communities.

Copyright @ 2019: This is an open-access article distributed under the terms of the Creative Commons Attribution license which permits unrestricted use, distribution, and reproduction in any medium for non commercial use (NonCommercial, or CC-BY-NC) provided the original author and source are credited. 
According to Barreiro [6], SCCs can be said to be places of focal points and vehicles for evangelization. The members of the SCCs are both hearers of the gospel and privileged beneficiaries of evangelization, as well as proclaimers of the gospel themselves and they do this both in words and in actions. In and through them, the poor hear the good news. Many Catholics today, through the SCCs have developed a new love for scripture and as such, they give witness to the truth of these words. DeSiano [7] noted that SCCs now explicitly discover the Word of God in the Bible as a source of nourishment for their religious life. The Word of God in scripture always serves as a source of inspiration and stimulation for their lives and actions.

This study was pegged on functionalism theory which focuses on contributions of various elements of a system. This is done through analyzing their contributions, which are called eufunctions (positive), dysfunction (negative) or, 'survival', that is, an element that makes no contribution at all or has outlived its purpose. The argument that we therefore make is that SCCs, are organs that are at the Church's micro level, are necessary components for evangelization, and are important in passing the message of Christ among members of these organs and communities around them. However, in their contributions towards the church they are faced with some challenges have affected their roles but they have always been able to overcome them .

\section{Objectives of the Study}

The study sought to meet the following objectives:

- Analyse the effectiveness of Small Christian Communities in Evangelization in the Catholic Church in Vihiga County.

- Explore challenges faced in evangelization in the Small Christian Communities in the Catholic Church in Vihiga County.

\section{METHODOLOGY}

The information contained here comes from two sources: First, library research and second, field research. Primary Data was derived from first hand information through in-depth oral interviews and questionnaires .Primary data was the main source data. Vihiga County was the study area whereby all the five Catholic Parishes namely: Luanda, Hambale, Buyangu, Chamakanga and Erusui were the focus of the study. Small Christian Communities within these Parishes were sampled purposefully for the survey. There are 279 SCCs in the five parishes. 74 SCCs were stratified sampled and for every SCCs sampled, a chairperson was purposely sampled for the study. Two respondents were picked randomly from each SCCs giving a total of 148 respondents.

To obtain qualitative data for analysis, in-depth oral interviews were through structured interviews which were subjected to the two respondents randomly picked in each SCCs. Open-ended questionnaires were administered to all the seventy four chairpersons in each SCCs. Inductive coding was used because the questions used were open-ended. Data was classified and coded into meaningful themes. Thematic analysis was used in analyzing data where major concepts or themes were identified and discussed. Data from open-ended questionnaires and in-depth interview were organized into themes and presented using verbatim excerpts. This shed light on the participants' responses to questions.

\section{EMPIRICAL FINDINGS \\ Effectiveness of SCCs in Evangelization}

The study aimed at getting views from various respondents on how they have benefitted from SCCs as far as evangelization is concerned. Data from 74 questionnaires administered in various SCCs in the Catholic Church in Vihiga County yielded the following information.

Table-1: Effectiveness of SCCs in promoting fellowship among its members

\begin{tabular}{|l|l|c|l|}
\hline & Variables & Frequency out of 74 & Percentage \\
\hline 1 & Encouraging unity among members & 67 & $90.5 \%$ \\
\hline 2 & Encouragement to lead a Christian life & 60 & $81 \%$ \\
\hline 3 & Deepening neighborhood fellowship & 58 & $78.4 \%$ \\
\hline 4 & Encourage members to participate in all SCC programmes & 57 & $77 \%$ \\
\hline 5 & Building relationship with non-catholic & 55 & $74 \%$ \\
\hline 6 & Dynamic of SCCs will encourage the liveliness of the parish & 54 & $73 \%$ \\
\hline 7 & Helps to build inter-personal relationship among members & 50 & $68 \%$ \\
\hline
\end{tabular}

\section{Source: Field Data from the Questionnaires}

From the questionnaires, $90.5 \%$ of the respondents stated that SCCs are very effective in encouraging unity among members while $81 \%$ pointed out that SCCs has also been effective in encouraging its members to lead a Christian life that is in line with the teachings of Jesus Christ. $78.4 \%$ pointed out that SCCs has succeeded in deepening neighborhood fellowship through weekly meeting and participation in various social and pastoral activities. SCCs have been in the front line in encouraging members to participate in all SCCs programmes. In addition, $74 \%$ of the respondents pointed out that SCCs has been very successful in building relationships with non- Catholics especially in time of need and in some occasions such as during funerals and weddings. $73 \%$ of the 
respondents pointed out that the dynamics within the SCCs encourages liveliness of the parish hence a sense of belonging. Lastly SCCs are also successful in building interpersonal relations among members. SCCs are like family where all their needs are met.

During the interview, respondents had the following views:

Respondent 2: We as members of SCCs are also concerned with the welfare of the sick. We visit them in their homes and pray with them. Sometimes members of SCCs we contribute money to buy drugs for the sick who may not be financially stable or in a position to buy drugs from the pharmacy. We also visit our sick members in hospital and pray for them and in some occasions we volunteer to take and accompany them in hospital to ensure they are well attended and assist where necessary. We inform the priest if the sick person requires the priest to visit him/her either for prayer or for the sacrament of the anointing of the sick.

Respondent 11: As members of SCC we address problems of alcoholism, drug abuse, family conflicts and other social problems that affect men and young people in our society today. We offer guidance and counseling sessions to the affected. We have at least in every SCC somebody in charge of guidance and counseling. The affected parties are visited often and assisted accordingly. The chronic ones have been assisted to join rehabilitation centers especially those under the influence of alcohol and drug abuse. We advice the relatives to take them to rehabilitation centers such as Asumbi Treatment Centre which is under the management of the Catholic Church. Those with family conflicts and other social problems their issues are addressed amicably in the SCC. We always try reconciling broken families. We are also in the forefront in the fight against stigmatization of the HIVIAIDS victims and the disabled.

Respondent 9: The introduction of Bible sharing during the weekly meetings has enabled us to read the Bible, meditate on it, and then put it into practice. Our faith is renewed and we know God better. SCCs have improved our relationship with our neighbors especially from other denominations since now with the biblical knowledge we don't feel inadequate before them. We feel encouraged and have developed the spirit of ecumenism.

It was pointed out that SCCs has been effective in caring for the needy in the community. These communities have encouraged the Christians and the entire neighborhoods to become aware of their mission within their families, extended families and the surrounding neighbors. They have become a source of help against the dangers that threaten the lives of the people in these areas. Issues such as child neglect, alcoholism and drug abuse, poverty, insecurity, crimes, hunger and many more are addressed at the meetings. The charitable individuals are at the service of the needy and the poor. By connecting life and what they draw from the Scriptures, on a day to day basis, their deeds are passed on to those in need of help. The put the Scriptural readings into practice and by so doing they are able to integrate the realities of life and their faith. They now transform family and parish life. The experiences of faith and community life in this religious environment are reflected in the lives of the people, in the parish and outside of it. Their cultural richness is shared in faith and love. There are some rehabilitation centers which are under the care of animators from the SCCs that caters for children with disabilities and street children within the county.

It was also reported that, SCCs have an impact on members, neighborhood, and the society. There is a remarkable change in the moral and spiritual lives of the members: they have become more generous, they support the Church financially, and actively participate in the life of the Church. Many Christians have regularized their situation in the Church through church weddings. With SCCs there is Bible reading and sharing which has helped the Christians understand the Word of God better. They are more engaged and involved in church activities more than in the past. SCCs have encouraged and brought about dialogue between Catholics and other denominations. It has galvanized Christian unity through mutual understanding and the use of the same Bible translation, exchange of invitations, and participation in the events of their counterparts. With SCCs people are now more responsible and consider the church as their own and not something that belongs to the priests and bishops. They are now aware of their responsibility to support the church and to play their roles in the church.

In addition, in one of the parishes a respondent pointed out that there is improvement in liturgical celebration and participation. This includes singing and reading in church, as well as preparing the prayers of intercession. It is no longer the work of the catechist alone to read in the church. Each SCC has a choir that animates the liturgy at the parish level according to the given schedule. Hence, the parish does not have to depend solely on the main choir for the animation of the liturgy. There is healthy competition among SCCs as each strives to produce the best choir.

Therefore it can be concluded that Catholics in Vihiga County have benefitted a lot from the SCCs. They have gained a lot from SCCs evangelization activities and these have contributed positively to the Catholic Church growth as echoed by functionalism theory.

\section{Challenges in Evangelization in the Small Christian Communities}

Although SCCs have been effective in evangelization, there is a lot that is yet to be achieved due to challenges encountered during weekly meeting. From the 74 questionnaires administered in 74 SCCs the following data was captured. 


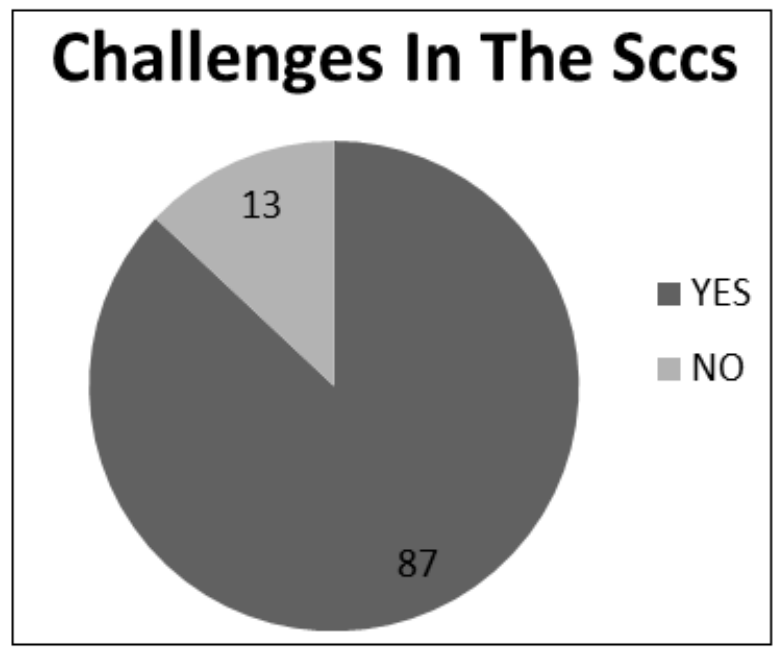

Fig-1: Challenges in the SCCs Source: Field Data

$87 \%$ of the respondents stated that there are challenges within the SCCs while $13 \%$ stated there are no challenges. The explanation in support to the response was as table below.

Table-2: Challenges in Evangelization in the SCCs

\begin{tabular}{|l|l|l|l|}
\hline & Challenges in evangelization in the SCCs & Frequency out of 74 & Percentage \\
\hline 1 & Lack of commitment among members & 65 & $87 \%$ \\
\hline 2 & Generation gap & 63 & $85 \%$ \\
\hline 3 & Hospitality & 63 & $85 \%$ \\
\hline 4 & Church dues collections & 61 & $82 \%$ \\
\hline 5 & Gap between the poor and the rich & 60 & $81 \%$ \\
\hline 6 & Poor male attendance & 60 & $81 \%$ \\
\hline 7 & Clanism & 55 & $74 \%$ \\
\hline 8 & Cultural conflicts & 45 & $61 \%$ \\
\hline 9 & Hand out mentality & 40 & $54 \%$ \\
\hline 10 & Ignorance & 30 & $41 \%$ \\
\hline
\end{tabular}

Source: Field Data

From the table above it is clear that there are many challenges in the SCCs which affect effective evangelization. 65 out of $74(87 \%)$ respondents in the SCCs stated that majority of the members of SCCs lacks commitment in the active participation in the SCCs. $85 \%$ outlined that there is a big generation gap between the young and the old therefore most SCCs are run and attended by the aged. Hospitality was also outlined as a challenged in many SCCs especially in town centers where people seems to be in a competition in welcoming guests during their weekly meetings. $82 \%$ don't attend SCCs meeting because they are not in a position of paying church dues or are unwilling to pay. In addition $81 \%$ pointed out that there is a wide gap between the rich and the poor in the SCCs and it affects its effectiveness. $81 \%$ reported of poor male attendance in SCCs weekly meetings and $74 \%$ claimed of experiencing clanism in the rural areas. Some areas stated to be experiencing cultural conflicts amounting to $61 \%$. In addition $54 \%$ were reported to be having a hand out mentality whereby thy expect the church to provide for them rather than being part of the church in the SCC and provide to the church. Finally, ignorance among some Christians has also affected evangelization as pointed above.

From the 148 respondents who were interviewed, the following was revealed:

Respondent 18: Some Christians are very mean. They don't assist the church in its development projects. They have money but they do not contribute at all in support of the church. Instead some decides to be dormant in the SCCS as a way of avoiding any contributions towards the church. They only re-service when a need arise to be assisted by the SCCs and the church.

Respondent 70: Hii Jumuiya yetu karibu sisi zote tunatoka katika ukoo mmoja (In ouSCC majority of us are from the same clan. Sisi hukosa kuelewana wakati mwingikwa sababu ya maswala ya kiukoo au kijamii na hii kufanya jumuiya kuvunjika. (We disagree in some occasions on clan or issues leading to collapse of SCC) 
Respondent 115: Our meetings are always rotated from house to house. Economically stable families at times seem to be in a kind of competition to outdo each other. Those who are economically unstable mostly fail to reach the standards that have been raised thus making them run away from these communities This mostly affected those living in small towns and business centers. This is a big challenge to SCC weekly meetings attendance.

Lack of commitment by some members has made some SCCs to remain inactive. Some participants complained that everyone claimed to be busy. Responses during the study indicated that most SCCs are active only when it is their turn to lead in mass. Weekly meeting attendance was poor compared to the registered members in the respective SCCs. In some SCCs, the activities of these cells had been left in the hands of the elderly people. The working class and the youthful groups always claimed to be committed elsewhere. This hindered their active participation in the SCCs. This concurs with Kurgat's [8] findings where she noted that in SCCs in the Catholic Church in Busia some members are not actively involved in their weekly meetings due to busy work schedule.

Age difference is another obstacle for the SCCs. Membership for SCC does not require any age difference but unfortunately in almost all SCC it was noted that youths normally shy off from attending any weekly meeting in the SCC. They do so because of generation gap or they fear being looked upon as children by the elders or they fear responsibilities in the SCCs. Alternatively, youth fail to join SCCs Simply because when the elders see them every message will be directed to them.

Hospitality is a virtue but sometimes can also be an obstacle in SCCs in the Catholic Church in Vihiga. It have been taken like a completion among Faithfull's to prove their financial ability hence making the less fortunate to feel inferior and to shy away from SCCs weekly meetings.

Most SCCs have come up with monthly contributions to raise money for the church dues at the diocese level. Responses from the respondents interviewed stated that every year every parish is supposed to contribute some amount of money to Kakamega Diocese towards the running of the various programmes and projects in the Diocese. Therefore, these contributions are shared among the SCCs and within the SCCs they are shared among individuals. That have become a stumbling block to many people especially those who are financially challenged. Many members have run away from SCC because they find it demanding a lot and they cannot pay the required dues.

SCCs meetings are mostly attended by those who are poor. The rich people only come in when contributions are required. This was reported during interview in SCCs in the rural areas where majority are peasant farmers. The rich were reported to have a tendency of sending their contribution to the group than attending the meetings and so defeat the whole objective of the SCC.

Women dominate most of the SCCs. Very few men attend SCCs meetings. Youths and children who are also supposed to be members of SCCs hardly attend SCCs meetings. Women are left to share their understanding of the bible without the input of men and youths which could be of great help to their spiritual growth as well as enhancing their evangelizing skills. This has weakened SCCs because all members have a role in the SCCs towards realizing the mission of the church in evangelization. Similarly, Kurgat [8] noted that most men do not attend SCCs meetings because they regard them as women affairs.

It was captured in many questionnaires that some SCCs comprise of members from the same clan. As a result there are some family/clan conflicts. Due to these family misunderstanding, some don't visit one another neither attend SCCs in such homes. Through the ministry of guidance and counseling in the SCC members are reconciled and in most cases it has yielded fruits

Respondents from certain locality pointed out that during a certain rite of passage season, there is always a crisis in faith which affects evangelization in the affected SCCs. Christians normally tends to be very conscious of their traditions more than their faith. Weekly meetings are poorly attended during these seasons. In some SCC some members were reported to have put a lot of emphasis on their traditions. In some occasions they don't give equal attention to SCCs meetings and activities because of superstitions based on their culture. Therefore they do not lend a hand in works of charity in the SCCs because of their beliefs. This affects evangelization which entails more than preaching (words). In support of this, Kurgat [8] noted that some Luhya strongly oppose the Church's prohibition of their culture, which they highly uphold. Christians need to sensitize on the need of embracing inculturation in evangelization.

It was also pointed out during the interview that there is a hand out mentality. Most Christians want to receive more than giving. They expect the church to give out everything but not to give to the church. It has affected development projects in the SCCs and in the church. Some SCCs are dormant because of their expectations and are only active when they are leading mass. A dormant $\mathrm{SCC}$ is a dormant church and no evangelization can take place.

In addition, it was also reported that some people lack knowledge of what SCCs are. They are yet to know the value of being a member of SCC. Some are forced by circumstances to be members of SCC. For instance no infant baptism can be done by any priest without consent of the SCC. Therefore, out of ignorance there are some seasonal members who attend SCCs weekly meetings 
in times of needs and crisis. With the help of the SCCs leaders the priests are trying to have home visitations to enlighten members for them to have a better understanding of SCC.

It was also reported and noted that Vihiga County have very many denominations which have a lot of influence to the SCCs members and all Christians within the locality. When SCCs are evangelizing, they seem to be in a form of competition and this has weakened some of SCCs. Some of the SCCs members have joined protestant churches where they think there is a better interpretation of the bible. This findings, concurs with Kilonzo's [9] findings where she reported that Vihiga county has many denominations which complete for members therefore influencing each other either positively or negatively in terms of membership.

\section{CONCLUSION}

The findings revealed that SCCs are very effective in evangelization through caring for the needy in various ways, they is remarkable change in the change in moral and spiritual lives of the members and improvement in liturgical celebration and participation. There are also a number of social and economic challenges encountered during evangelization and SCCs are trying to handle them as they occur. Nevertheless, the challenges have not affected the effectiveness of evangelization within the SCCs.

\section{RECOMMENDATION}

The study recommends that challenges in evangelization within the SCCs should be minimized at all cost by creating a friendly environment where all members will be in a position to interact freely. In doing So, SCCs will be very effective in evangelization and the church will achieve its Mission of Evangelization to all right from the grass root.

\section{REFERENCES}

1. Flannery, A. (1988). Dogmatic Constitution on the Church: Lumen Gentium, Vatican Council II: The Conciliar and Post-Conciliar Documents, vol. 1, Dublin: Dominican Publications, 357-358.

2. Healey, J., \& Hinton, J. (2007). Small Christian Communities Today. Capturing the New Moment. Religious Study Review Journal, 33(1), 34-35.

3. Healey, J. (2009). Innovations and new trends in small Christian communities (SCCs) in Africa today. Hekima Review journal, 40: $85-100$.

4. Kamwendo, J. F. (2012). The diaconal role of the roman catholic church within the diocese of Lindi Southern Tanzania: an assessment of its transformational development (Doctoral dissertation, Stellenbosch: Stellenbosch University), 4-5.

5. Kurgat, S. (2009). The Theology of Inculturation and the African Church. International Journal of Sociology and Anthropology. 1 (5), $90-98$.

6. [1] Barreiro, A. (1982). Basic Ecclesial Communities. The Evangelization of the Poor, Translated by Barbara Campbell. New York: Mary knoll. Orbis Books.

7. Desiano, F. (1993). Creating the Evangelizing Parish. Paulist Press, New York. Mahwah.

8. Kurgat, S. (2004). The Catholic Church and Social Change in Busia District, Kenya 1924 1995. Unpublished PhD Thesis, Maseno University press.

9. Kilonzo, S. (2008). Christian Diversity and Community Development in Vihiga District Kenya. Unpublished PhD Thesis. Maseno University Press. 